Revista

ACor

das Letras

\title{
Relações de poder: sedução e religiosidade em Maria Luissa, de Lúcia Miguel Pereira
}

\author{
Power Relations: Seduction and Religiosity in the Configuration of \\ Maria Luísa, by Lucia Miguel Pereira
}

Edwirgens Aparecida Ribeiro Lopes de Almeida* Universidade Estadual de Montes Claros, Montes Claros, Minas Gerais, Brasil

\begin{abstract}
Resumo: O presente texto tem o propósito de estudar as relações de poder configuradas pela educação religiosa católica e pela sedução masculina exercidas sobre a personagem Maria Luísa, na obra homônima, de Lúcia Miguel Pereira. Publicada em 1933, Maria Luísa traz intensa sintonia com os princípios ideológicos daqueles tempos e conserva, de certo modo, uma preocupação com a ordem social, prevista e reiterada pelos meios de difusão do pensamento católico, como a revista $A$ Ordem, a quem Lúcia contribui como escritora.
\end{abstract}

Palavras-chave: Religião. Sedução. Mulher. Tradição.

Abstract: This paper aims to study the power relations set up by Catholic religious education and male seduction which have exerted influence on the character Maria Luisa, in the work of the same name, by Lucia Miguel Pereira. Published in 1933, Maria Luisa is in intense consonance with the ideological principles of those times and has preserved, in a sense, a concern with social order, both foreseen and reaffirmed through the means of Catholic thought diffusion, as the publication A Ordem to which the author cooperated as a writer.

Keywords: Religion. Seduction. Women. Tradition.

Qual de nós não alimenta dentro de si, o ideal de um livro inteiramente sincero, livre, de um livro gerado nas raízes da personalidade, carregado do mistério vital? De um livro que penetrasse muito fundo na alma dos homens, e os acordasse do marasmo em que se atolam? (PEREIRA, 1992, p.89).

Lúcia Miguel Pereira: crítica e historiadora da literatura, biógrafa de Machado de Assis e de Gonçalves Dias foi também uma romancista. Escrevendo quatro romances destinados a adultos, Maria Luisa, Em Surdina e Amanhecer na década de 30 e Cabra-Cega na década de 50, Lúcia ainda se aventura no universo mágico infantil quando elabora, entre 1939 e 1943, A fada menina, A floresta mágica, Maria e seus bonecos e A filba do Rio Verde. Com

* Doutora em Literatura pela Universidade de Brasília UNB (2010), Doutora em Língua e Literatura espanhola e hispano-americana pela Universidade de São Paulo USP (2013) Mestre em literatura brasileira pela Universidade Federal de Minas Gerais UFMG (2007) e graduada pela Unimontes em Letras Espanhol (2003), graduada em Letras/português, pela Unimes (2015). Professora do Programa de Pós-graduação em Letras/Mestrado e do Departamento de Comunicação e Letras da Universidade Estadual de Montes Claros. E-mail: edwirgensletras@gmail.com. 
um acervo romanesco pouco lido e estudado, sobretudo nos dias atuais, a autora ainda figura como referência na crítica literária nacional, mormente por ter sido uma das primeiras brasileiras a alcançar êxito no exercício de uma tarefa pouco desbravada pelas mulheres nas primeiras décadas do século XX.

Uma leitura do legado crítico e romanesco de Lúcia Miguel Pereira revela o quanto a sua produção esteve sintonizada com os acontecimentos políticos e ideológicos do tempo seu contemporâneo. Como é sabido, é intenso o envolvimento e atuação de Lúcia com a tradição católica dos primeiros anos do século XX, escrevendo para um dos principais meios de difusão do pensamento religioso naqueles tempos, a revista $A$ Ordem. Por outro lado, a autora também declarava não se vincular a nenhum partido político ou a crença religiosa. Carlos Drummond de Andrade, em trecho de seu diário de 1959, citado por Bernardo de Mendonça esclarece: "Octavio (Tarquínio de Sousa) disse que sua mulher, Lúcia Miguel Pereira, também não pratica qualquer credo religioso..." (MENDONÇA, 1992, p. xix).

Adentrando aos relatos narrativos e, sobretudo à primeira narrativa ficcional publicada por Lúcia Miguel no ano de 1933, Maria Luisa, é possível se deparar com a relevância do contexto histórico e do discurso religioso na concepção de seus enredos. Tendo em vista tal postura da artista, Antônio Candido relata que Lúcia "se preocupava muito com os problemas do espírito e da conduta em relação ao seu tempo" (CANDIDO, 2004, p. 127). É ela mesma quem ratifica essa postura ao afirmar, no trecho destacado como epígrafe o anseio de que a escrita "penetrasse muito fundo na alma dos homens, e os acordasse do marasmo em que se atolam". Diante desse propósito, é lícito declarar que o universo ficcional concebido por Lúcia na narrativa Maria Luisa, circunda, essencialmente, as inquietações femininas e sua condição social permeadas, mormente pelo discurso da ordem familiar, orientado pela religião católica.

Convém acrescentar que, no Brasil, a igreja católica agiu, durante séculos, com muito rigor sobre a vida social e, sobretudo, familiar. Nos anos trinta é ainda intensa a ação dessa instituição no controle e orientação da vida material, intelectual e sexual de seus seguidores. Transpondo o limiar entre escrita jornalística e registro ficcional, Lúcia Miguel Pereira tece, neste último, os juízos, o modo de vida, até mesmo os preconceitos, as hierarquias e as hipocrisias construídas à base de uma educação, sobretudo, religiosa. É o narrador quem esclarece que "uma vez rotulada Católica Apostólica Romana, só via um caminho a seguir: sujeitar-se a umas tantas regras, aliás, facílimas para uma mulher honesta; e esperar com tranquilidade uma recompensa certa - e merecida" (PEREIRA, 2006, p. 56). A partir das contradições em que a narrativa é construída, poderá haver, na opinião do narrador, uma ironia sobre a condição feminina, uma visão muito simplificada da vida. O ponto de vista apresentado é de intensa crítica, sobretudo quando destaca o narrador serem 'facílimas' as regras a serem seguidas pelas mulheres, quando essas mesmas regras pregam a submissão e a subserviência ao homem.

Para discutir a ação do discurso religioso sobre a personagem Maria Luísa é preciso examinar as relações de poder a que estavam submetidas as mulheres frente à ação masculina e redefinição ideológica dos anos 30. Nesta obra, a crítica à tradição e ao conservadorismo sobressai aos incipientes traços da modernidade, em que a presença de 
um homem, a personagem Flávio, irrompe como uma figura epifânica, uma estratégia narrativa a fim de revelar a individualidade de outras personagens como Maria Luísa, Lola e seu amigo Artur. Essas distintas personalidades são motivadas pelas várias ideologias que coexistem ao longo dos anos 30. Com isso, o romance Maria Luísa é estruturado em duas partes bem definidas. A primeira delas simplesmente denominada "Parte I" e a segunda intitulada "A Montanha", ou poderíamos também declarar que a estrutura da narrativa manifesta-se como "antes" e "depois" de Flávio. Diante dessa constatação, Flávio surge como estratagema no conhecimento próprio dos outros figurantes do romance. É ele o espelho no qual são irradiadas as imagens das personagens, e a partir do que, essas imagens entram em um processo de desagregação, travestidas de novas roupagens, ou pelo menos, de novas ideias.

Carregando as marcas da educação tradicional, Maria Luísa nutria verdadeiro horror pelo mundanismo e nunca havia frequentado bailes, por isso, na ocasião das férias dos filhos, preferia viajar para um lugar tranquilo, nos arredores do Rio de Janeiro, pois ela sentia-se bem no recolhimento. Nunca imaginara outra existência diferente daquele restrito mundo familiar que a ela lhe bastava. Esse pequeno mundo no qual a protagonista se comprazia juntamente com o seu grupo parental estaria prestes a ser desvelado pela presença do amigo de Artur- 'sempre o mesmo, o malandro, sempre original' - o Flávio Moura. Procurando conciliar os seus dois senhores, a saber: o amigo e a esposa, Artur, envolvido com questões de trabalho, embarca Flávio sozinho ao encontro de Maria Luísa, que se encontrava em uma pousada com os filhos. Flávio ia furioso com Artur, pois não tinha grandes afetos pelos lugarejos do interior e, além disso, repugnava-lhe as posturas da burguesa preciosa, 'conservada em água benta' que diziam ser a esposa do amigo. Alguns traços dessa personagem colocam o leitor suspeito de sua vinculação aos ideários anarquistas, princípios, de certo modo, criticados pela voz narrativa. Também nessa questão, vale acrescentar que, portando uma forma de rompimento com a conduta tradicional, ressaltada na ficção por algumas personagens e pelo narrador, é Flávio o elemento desencadeador da desordem nesse núcleo familiar. Como um sedutor moderno, Flávio não compreendia as razões de uma união convencional mantida sobre os princípios religiosos. Sentia-se atraído por mulheres mais liberais, desprovidas dos compromissos manifestados nas relações conjugais. Tais características eram as opostas de Maria Luísa, motivo que o faz, inicialmente, ter repulsa por ela. Porém, o sedutor se surpreende ao conhecê-la.

Assim também Maria Luísa se surpreende com Flávio, já que não era simples e amável qual se mostrou quando o imaginava. "Nunca prestara muita atenção ao que, sobre, e as suas viagens, e o seu talento, lhe contava o marido. Não a interessava. Um gozador vulgar. Um inútil. Um indivíduo fora da sua órbita. Por quem a humilhava a admiração um pouco servil de Artur" (PEREIRA, 2006, p. 69). Pela elucidação da personagem, pode-se notar certo ciúme, ou certa competição da esposa, a respeito da influência exercida por Flávio sobre Artur. Maria Luísa se comprazia com o controle que ela mesma exercia sobre a família e sobre o marido. Porém, começou a se sentir atraída por aquele homem sedutor, um tipo de Don Juan. Trazendo algumas vestes do Don Juan, 'personagem-símbolo significativo (e fecundo) da cultura do Ocidente', criado no século 
XVII, pelo escritor espanhol Tirso de Molina, Flávio encarna bem esse lendário protótipo de homem conquistador e desprovido de preocupações com a religiosidade, por isso Maria Luísa o descreve como 'um indivíduo fora da sua órbita'. De modo contraditório ao daqueles homens com os quais conviveu a protagonista naquele ambiente tradicional, Flávio figurava para ela como um elemento estranho.

Assim como faz o sedutor de Maria Luisa, na ficção espanhola, Don Juan sente-se fortemente atraído por Ana apenas ao ouvir o Marquês de la Mota falar sobre e de seu amor por ela. Como observa Sócrates Nolasco sobre o mito espanhol, desprezando os princípios religiosos, Don Juan privilegia "enganar as mulheres e depreciar os homens com os quais elas estão comprometidas" (NOLASCO, 2001, p. 264). De maneira análoga, nesse jogo de sedução, Flávio despreza a sua amizade por Artur e lança mão de todos os meios de conquista. Para ele, a mulher não tinha importância, precisava satisfazer a seu próprio ego, "pelo prazer sempre novo e sempre inebriante de sentir a força do seu poder de fascinação... além disso, tinha o seu encanto, esse vulto de uma mulher que não via, que nunca vira... e justamente porque não a conhecia, podia imaginá-la, ... cheia de encantos" (PEREIRA, 2006, p. 70). Conforme acrescenta Nolasco, o homem que se assemelha ao paradigma do Don Juan:

diverte-se com os resultados de suas trapaças, e só pode fazê-lo porque habita em um mundo no qual a aceitação dos códigos morais, sociais e religiosos é puro fingimento. Dom Juan é um representante do veio individualista na medida em que não mede esforços para conseguir o que deseja; para ele, mentir é indiferente, como também o é entrar em conflito com a sociedade e suas regras. Ele manipula o código de honra segundo seus próprios interesses e é astuto no manuseio dos códigos de lealdade familiar e do amor cortês. [...] Dom Juan é uma ameaça contínua às famílias, valendo-se da situação privilegiada de sua própria família (NOLASCO, 2001, p. 265).

Um olhar atento à dinâmica da ordem e da desordem em que se assentava a sociedade histórica contemporânea da publicação de Maria Luísa deixa ver que é o contexto que permite a inserção desse protótipo construído na Espanha e, Lúcia propositadamente o transporta para a realidade ficcional brasileira. Com a inserção dessa personagem, através de sua relação com os demais integrantes da cena literária, mostra a crise, a falsidade das estruturas nas quais estavam assentadas a família naquela sociedade ficcional, ou talvez o faça alegoricamente, referindo-se extensivamente ao Brasil. Pela citação acima exposta, é pertinente traçar o paralelo entre Don Juan e Flávio. Este, assim como o sedutor espanhol, não se preocupa com o sentimento gerado na seduzida Maria Luísa, tampouco se inquieta com as regras estabelecidas pela religião. Contudo, é curioso ressaltar que a visão dissimulada acerca da sociedade é despertada na amante, a partir do contato com ele. Nesse sentido, Flávio não se sente constrangido, inclusive com a presença do amigo-marido de Maria Luísa. Age com naturalidade ao retornar ao seio do lar da ex-amante e, com toda essa discrição, pode ser considerado um perigo iminente à ordem familiar. Acerca dessas estratégias de afirmação da sexualidade, Elisabeth Badinter (1993) e Sócrates Nolasco (2001), comungam do pensamento de que, nas sociedades 
patriarcais, um dos fatores mais significativos reside na conquista de muitas mulheres sem ser conquistado.

Do outro lado, Maria Luísa se sentia à vontade ao lado de um homem 'talentoso e requintado’.

Nas longas horas que passavam a conversar, Maria Luísa ia vendo aparecer de manso, e sorrateiro, um novo Flávio, mais interessante ainda, porém mais perigoso. Mas não se lembrava de que era semelhante ao que imaginara - e condenara. Não se lembrava de nada. Como o poderia fazer? Só conseguia ouvir... Não sem revoltas interiores, mas ouvia (PEREIRA, 2006, p. 72).

Embora percebesse em Flávio os vícios que criticava no homem, era incapaz de lutar contra ele. O contato com o 'novo', com um homem cuja postura se distinguia daquela de seu marido a faz transgredir os protocolos nos quais estava estruturada a sua conduta de esposa exemplar. Através da sedução, Maria Luísa é conduzida a uma verdadeira mudança, na qual Flávio é o despertar da sua consciência:

E todo um mundo ia surgindo aos olhos deslumbrados da moça. Todo um mundo nunca suspeitado, um mundo livre, colorido, brilhante... Enquanto o outro, aquele em que sempre vivera, parecia desmoronar-se, pulverizado pelo jato impiedoso da ironia... Às vezes, valentemente, queria reagir; tentava defender o seu universo, que lhe parecia um sacrilégio ouvir desrespeitar assim. Mas logo se calava" (PEREIRA, 2006, p. 73).

Seduzida como as criaturas do século XVII, diante dos desequilíbrios e da desagregação de valores, sobretudo do jogo de aparências, que compunham aquele universo do mundo em que está inserida, a personagem de Lúcia Miguel Pereira repreende Flávio publicamente, mas o admira às escondidas. Visível se torna o embate entre velhas e novas ideias. Com esse mecanismo ficcional, a autora realça um embate social sobre as ideologias predominantes nos anos 30, o relevante papel da espiritualidade na configuração da ordem social e os movimentos 'modernos' que ela mesma vai pôr em debate em seus romances. Contudo, apesar de conter publicamente os seus ímpetos de mudanças estavam abaladas as suas convicções. Maria Luísa passa a se sentir incomodada, fragilizada e dominada pela ação de Flávio sobre si, pois, ele era como um espelho que refletia sua nova personalidade.

Tỉnha a impressão vertiginosa de estar sendo arrebatada por um espaço de dimensões infinitas, em que se perdiam todos os seus pontos de referência. Flávio a interrogava, como uma insistência amável e dominadora, contra a qual se via sem defesa. Eram perguntas incisivas, diretas, que a obrigavam a olhar para dentro de si. Para regiões que nunca explorara. E acordavam nela uma mulher desconhecida, revoltada contra a mesmice da vida, vibrante de loucas aspirações (PEREIRA, 2006, p. 73).

Vemos, nesse fragmento, o 'poder' motivador de transformações que Flávio exerce sobre a personagem e, consequentemente, sobre o enredo da narrativa. Conforme vimos reiterando, Maria Luísa depara-se com o comodismo e o conformismo frente a sua condição de mulher casada, mãe, isto é, uma vida organizada nos modelos burgueses. 
Flávio é, nesse ínterim, um mediador dessas transformações, porque, nega essa forma de vida regrada e previsível. Diante disso, a inserção dessa personagem é, a nosso ver, o ponto de desagregação da velha ordem, como seriam, no plano histórico, as ideias anarquistas e comunistas sobre a tradição. O trecho supracitado é revelador da importância atribuída à presença de Flávio na narrativa, mais ainda à relação de alteridade construída entre a autora e a personagem. A reflexão da personagem extraída da ficção nos remete facilmente à opinião da autora proferida na epígrafe que inicia este capítulo, quando a mesma vislumbra ser a literatura um objeto de descortinar a personalidade humana, penetrando 'muito fundo na alma dos homens, e os acordando do marasmo em que se atolam'. Trata-se, no entanto, de um artifício poético da autora para pormenorizar na ficção suas experiências pessoais.

Tal citação traduz bem esse momento de transição que desequilibra o "universo" feminino transplantado na ficção ratificando o embate tanto pessoal quanto coletivo em que a obra foi concebida. Esse embate vai culminar na dialética da ordem, baseada no discurso religioso, androcêntrico e patriarcal, e da desordem, baseada na mobilidade dos valores morais e das atitudes do mundo moderno. Nessa direção, a personagem Flávio parece simbolizar esse espírito de modernidade contra o qual é impossível lutar, que faz algumas pessoas refletirem sobre a sua condição, pois 'eram perguntas incisivas, diretas, que a obrigavam a olhar para dentro de si'. E provocando essa desestabilização dos laços domésticos, revelou nela 'uma mulher desconhecida, revoltada contra a mesmice da vida, vibrante de loucas aspirações'. Aspirações que, no desfecho da história, não são realizadas em detrimento do silenciamento a que ainda era submetida a mulher, e sobretudo, a narrativa tece tal crítica porque, para uma mulher na condição social de Maria Luísa, era contra as práticas dominantes um modo de vida diverso daquele que ela vivia.

Flávio conquista mais pelas palavras que por gestos. "Pouco delicado em ações, erao, escrupulosamente, em palavras e no cumprimento das pequenas regras de civilidade. Seria capaz de desviar uma mulher do seu caminho - mas nunca de passar antes dela por uma porta..." (PEREIRA, 2006, p. 87). Este trecho talvez exemplifique a falha de Artur, o marido. Apesar de ser em parte conduzido pela esposa, era o marido modelo das sociedades tradicionais, pois cumpria apenas o seu papel de provedor da família. A trama narrativa chama aqui a atenção para a subjetividade feminina, a necessidade da realização no lado afetivo que Maria Luísa nem se atenta para ele, mas que é despertado pelas atitudes gentis de Flávio. É por isso que ela sente que o sedutor dera vida a uma 'intrusa inquieta e inquietante' dentro dela. A Maria Luísa autoritária e autônoma se satisfazia com a relação mantida com o marido, já a emocional, frágil e sensível precisava de um novo modelo de homem. Oscilando entre os dois, extremos opostos, ela confundia seus sentimentos, se sentia desejo ou temor por Flávio. Pelo marido, sentia revolta já que ele, por seu excesso de confiança e admiração pela esposa, fora incapaz de impedir tal acontecimento. Em alguns momentos, achava-o ridículo.

Revoltava-se contra o marido que não a soubera prender, que a julgara estátua autômata, quando era mulher; mulher como as outras, mais fraca do que as outras. Culpava-o porque fora neutro, amorfo, porque não a soubera fazer vibrar. Porque acreditara que ela era o que 
mostrava ser. Porque a revelara a si mesma. Porque a admirara, em lugar de dominá-la (PEREIRA, 2006, p. 80).

A personagem central questiona aqui o ato de dominação do homem sobre a mulher, pois, para ela, fora a liberdade concedida pelo marido que possibilitou o seu contato com a vida 'real', a vida dos vícios, entretanto dos prazeres. A constatação da fraqueza feminina a aproxima de Lola, a quem ela havia se sentido tão superior, e contrasta com o ponto de vista da sua mãe de que as mulheres eram mais fortes que os homens, por isso deviam guiá-los sem que eles o percebessem.

A sedução de Flávio evidencia a vida de aparência, o desencadeamento de suas sensibilidades, fraquezas e estabilidade que a vida familiar a provia. Para Maria Luísa, suas vivências constituíam uma hipocrisia e era preciso mentir, por isso ela continuava com suas tarefas diárias, mesmo mergulhada numa luta interior. Com isso, o desejo masculino era concebido como uma tentação e, pensando de maneira diversa da mãe, achava fracas as mulheres, aquelas que não haviam caído era porque não haviam sido tentadas. Por meio desse pensamento, a protagonista ratifica traços de religiosidade católica quando rememoramos que, no relato de Gênesis, a mulher, simbolizada por Eva, é a encarnação da apatia e do pecado, motivo que transporta para a sexualidade feminina a sensibilidade, a vulnerabilidade e a fraqueza. Sendo assim, fica evidente a impostura, a aparência da educação doutrinada pelo catolicismo que receberam ela e a irmã Célia.

Em frases curtas, marteladas e ardentes, disse o seu horror pela educação que recebera; o crime de fabricarem os pais um mundo imaginário para as filhas, que tarde ou cedo descobrirão o engano de que foram vítimas. Célia tivera a melhor parte; não chegara a viver, a verificar à sua custa a falência das ideias que lhes haviam incutido (PEREIRA, 2006, p. 83).

Fica explicitada, nesse trecho, a crise dos valores, o desvelamento das certezas que a educação tradicional desencadeara no estabelecimento da família. A expressão 'o crime de fabricarem os pais um mundo imaginário para as filhas', externa a descrença a que a sociedade, experimentando novas vivências, começa a dar visibilidade. Sob um prisma irônico, é, para a protagonista, esse mundo ilusório o culpado pelas fantasias femininas que as aproximam do erro, porque a vida não era um romance, mas um livro cruel, e todas as convicções uma grande mentira.

Voltando à primeira parte do livro, o narrador, criticando as caracterizações das virtudes e da ordem dos preceitos tradicionais, compara a mulher e sua inocência à de uma criança, sem maldades e vícios. E destaca:

quando termina essa fase, quando vacila a noção de um mundo definitivo e perfeitamente estabelecido, está acabada a infância, seja qual for o número de anos dos que aprenderam a duvidar - e a comparar. A comparação é quase sempre uma porta aberta à infelicidade. Ou pelo menos ao descontentamento. Parece que há gente privilegiada - ou inconsciente - que, sob esse ponto de vista, nunca sai da meninice... que nunca descrê dos outros, nem de si... (PEREIRA, 2006, p. 25). 
É essa infelicidade e esse ceticismo provocados pelo rompimento das expectativas que se dão com Maria Luísa nessa relação de alteridade com Flávio. A experiência do contato, da visão do outro, é que permite à protagonista compreender o seu mundo a partir de um olhar diferenciado. Nisso, vê-se o aspecto negativo imputado à libertação das regras sociais impostas à mulher.

É visto que, na primeira parte do romance, através da fala do narrador, há um olhar de fora para dentro dos fatos e do pensamento das personagens. Essa estratégia de transformar o leitor espectador da criticidade do narrador e de colocar a crítica em detrimento dos fatos, parece justificar a concepção da narrativa que resulta do ímpeto de exteriorizar e questionar o clima ideológico bem como a condição da mulher naqueles anos. E como a obra tem certa correspondência com a vida real, seus valores são, em certa medida, os da vida real. E os valores ideológicos contemporâneos à criação são, inevitavelmente, transferidos para a ficção. E assim, através do narrador, a ficção assume o seu papel de colocar em debate a ordem vigente.

$\mathrm{Na}$ segunda parte, é a própria personagem central quem, de dentro para fora, externa as suas angústias e crises existenciais a fim de alcançar a libertação, ou pelo menos o conhecimento das máscaras que enredam a sociedade em que se encontra. Como se não quisesse compactuar com a inovação da protagonista, o narrador lhe permite conduzir o leitor. Sobre a questão, Luís Bueno comenta que é:

interessante como, nesse aspecto, o narrador sempre tão presente, assumindo, a todo o momento, a tarefa antipática de julgar sua heroína, afasta-se. Em nenhum momento o que aconteceu entre Maria Luiza e Flávio é objeto de censura por parte do narrador. Toda condenação e toda culpa vêm da própria personagem (BUENO, 2006, p. 314).

Conforme esclarecemos, a discussão sobre o discurso predominante através da ironia e da crítica à ordem tradicional se dá nessa narrativa por meio de algumas mudanças de pensamentos ou pela conformação. Neste segundo momento, não mais o narrador, mas é apropria Maria Luísa quem presume o choque entre sentir e pensar que, a partir desse momento, irá se concretizar no seu percurso. Ela mesma confessa que, "sempre pensara o que sentia, estava agora a sentir o que pensava" (PEREIRA, 2006, p. 57).

Essa mediação entre o ser e o pensar passa a tematizar gestos e sentimentos mais contidos que liberados frente à dialética do homem e da ordem social estabelecida. Como ficou esclarecido, Maria Luísa, embebida de um conflito interior, passa a refletir, ainda que se mantenha silente de sua situação. É nesse contato que surge a mulher consciente, mas inoperante. Neste sentido, cessa a sua inocência, despida através deste espelho que foi para ela, o contato com Flávio, começa a se operar a revelação de novas identidades pessoais dentro desse mundo estruturado pela hipocrisia social. Para ela, numa sociedade de condutas aparentes parecia ser virtuoso quem melhor soubesse fingir.

Esse universo maniqueísta e bem delineado, sobretudo pela religiosidade, é que primeiro será desconstruído, ou pelo menos, criticado, na trama. Para a protagonista, o autoconhecimento e o conhecimento da sociedade produzia o sofrimento, a desilusão, por isso era preciso colocar os filhos numa instituição de ensino zelado por padres, já que era necessário saber mentir e "não lhe cabia, a ela, a ela indigna e corrompida - reformar 
os métodos de educação... religiosos mentiriam com maiores aparências de verdade" (PEREIRA, 2006, p. 89). Criticamente revela que ela não tinha coragem de abrir os olhos dos filhos para a vida, era melhor ser criados 'criminosamente' como ela o fora, mas teriam alguns anos de felicidade.

Interessante notar o contraste estabelecido na narrativa já que Maria Luísa fora educada por intermédio da doutrina católica, embora, desde o primeiro capítulo da história, vá sendo traçado o descompasso entre o discurso e a prática religiosa da mesma. Mostrando essa desarmonia, sua prática amorosa extraconjugal põe em evidência intensa crise moral, como é destacada na segunda parte do romance. De acordo com as elucidações do narrador, ainda na primeira parte:

[n]o mundo moderno, convulso e desorientando, a Igreja Católica avulta, para muitos espíritos, como escola de ordem, de disciplina, de respeito à autoridade.

A imutabilidade dos seus dogmas, a rigidez incorrupta das doutrinas que vem sustentando há vinte séculos the granjearam admiradores entre aqueles que só a apreciam no plano humano. Que negam a sua essência - a origem divina - e o seu fundamento - a mansuetude misericordiosa do Evangelho.

Sem o saber, Maria Luísa filiava-se em parte a essa corrente (PEREIRA, 2006, p. 56)

A apreensão ficcional dos atributos do catolicismo é bastante condizente com o legado deixado por Lúcia Miguel Pereira para a revista religiosa $A$ Ordem. Acerca da influência da religião sobre esses escritos, Márcia Cavendish Wanderley esclarece que,

Lúcia Miguel Pereira não escaparia a esse clima nostálgico de tradições e valores religiosos que envolvia a todos. Filha de tradicional e católica família mineira já trazia, na sua formação inicial, a predisposição à absorção de tais ideias, fato que irá comprovar-se com a publicação de seus primeiros artigos na revista A Ordem (WANDERLEY, 1999, p. 74).

É bem irônica essa postura do narrador, ora da personagem de atribuir aos preceitos religiosos a conduta do bem e da aparência na garantia da vida moral. Seguindo essa trilha, Maria Luísa segue a sua rotina de vida descrente daquilo que praticava, e ainda assim, frequentava as missas, olhava o movimento da igreja, as pessoas que entravam e as que saíam. Vendo as mulheres se confessando, teve necessidade de se revelar a alguém, e não pretendia livrar-se da culpa, mas do segredo. Queria revelar-se a um homem como qualquer outro, desejava um confidente, não um confessor. Como explica:

Não era o sacramento que a atraía, não era ao ministro de Deus que se queria confiar. Era àquele padre, a um homem; a um homem feito de lama e de pecado como também ela o era; a um homem que a compreenderia, talvez... porque era apenas humano... um homem passível de fraquezas, de sofrimentos, de ternura; e não somente o representante de um Deus longínquo, frio e impiedoso (PEREIRA, 2006, p. 134).

Driblando as inquietações interiores e o desacordo religioso, a protagonista revela que "se noutros credos existisse o Tribunal da Penitência, se fosse budista ou protestante, ou maometano aquele sacerdote, teria o mesmo ímpeto de se arrojar a seus pés" (PEREIRA, 2006, p. 133). Como comenta Márcia C. Wanderley (1999), o clima moral e 
intelectual dominante no Brasil dos anos vinte e trinta foi um clima permeado pela religião católica, a fala supracitada revela o estado de apostasia em que se encontra a personagem.

Constituindo-se essa metáfora de um elemento especular em que é refletida a imagem de outras personalidades da narrativa, Flávio, a nosso ver, migra da condição de coadjuvante a personagem principal, já que todo o romance se constrói através de constante relação de alteridade a partir dele. Depois de espelhada a sua identidade nesse simbólico espelho, Maria Luísa se conhece melhor e interpreta coerentemente a cunhada Lola, o marido Artur e o amante Flávio. Perdido o encantamento, entende que havia cedido a um conquistador vulgar que buscava novas emoções, ela passou a ter horror de si mesma e descobriu que não o amava. "Tivera o atrativo único de ser o fruto proibido, a mulher do amigo, a mãe de família impecável. Caíra facilmente, como uma burguesinha tola e sentimental... A mais banal, a mais humilhante das aventuras" (PEREIRA, 2006, p. 78). Materializando esse símbolo pecaminoso e proibido, a heroína comporta os atributos que coadunam com os ensejos do conquistador à moda Don Juan. Em virtude de seus princípios, o sentimento provocado na protagonista se baseia no inflexível discurso da época de que, conforme destaca Mary del Priore falando sobre os anos 30, 40 e 50, "[a] 'senhora casada' não poderia jamais preferir outra companhia à de seu marido, nunca procurar seduzir corações masculinos, manter correspondência secreta ou esconder alguma coisa do cônjuge, pois tudo isso concorreria para ameaçar sua "respeitável posição" assim como para alimentar sua infidelidade” (PRIORE, 2005, p. 288).

Mesmo sentindo a humilhação do 'fastio mal disfarçado de Flávio', Maria Luísa atribui importância ao encontro com ele porque havia sido libertada do seu eu mesquinho e calculista, da 'vida morna como as águas paradas'. A metáfora utilizada 'vida morna como as águas paradas' é capaz de traduzir a mesmice do cotidiano das mulheres casadas. Apesar da desestabilização provocada pela união de Flávio a Maria Luísa, esta reconhece a necessidade do outro para poder enxergar a si própria, mesmo que estivesse convencida de aceitar a máscara da aparência, pois mesmo que estivesse errado o passado, o futuro estava delineado por ele.

Restaurada a antiga e aparente tranquilidade no lar, a família decide viajar para Petrópolis a fim de descansar, nas férias. Notado o receio do esposo de que a presença de Tia Laura, outro ser estranho ao núcleo familiar, rompesse a monotonia daqueles dias, Maria Luísa sugere a Artur que peça a Lola para enviar sua filha Rosita. A reação de Artur é enfática ao caracterizar o procedimento da cunhada, que vivia 'quase abertamente' com o Dr. Santos. Era o mesmo que desvalorizar a família, afinal, vivia Rosita em companhia da mãe, e, poderia herdar as características dela. A atitude preconceituosa de Artur reproduz os mesmos argumentos de Maria Luísa antes dessa transição em sua vida. Para ela, as palavras de Artur eram como o seu velho eu falando pela boca do marido.

Diante da atitude do marido, ela percebe a repercussão de seus atos nas relações familiares, e toma ciência de que o resultado da ação de Flávio sobre ela provocaria uma mudança maior. Estava tomada por uma nova forma de pensar que a perseguia, talvez de forma mais enfática que suas ações. Os seus atos a manchavam, mas suas ideias conseguiam alcançar e corromper os outros. Inquieta com as atitudes do marido, ela passa 
então a se questionar como mostraria ao marido que não tinha o direito de ligar a filha à conduta da mãe, que a sobrinha não era em nada inferior a seus filhos.

Com uma nova forma de ver os outros, Maria Luísa se põe diante de uma inusitada situação, abrir os olhos do marido explicando-lhe que não tinha o direito de julgar, mostrando-lhe a necessidade de duvidar de si mesmo. Dessa maneira, a mudança que se operara na protagonista também é refletida em Artur, já que a mesma, embora perseguida pelas suas antigas ideias, constata que o melhor é quebrar o estereótipo do correto passando a duvidar do conhecimento de si mesma. Pelo que vimos ressaltando, é o próprio conflito social que permitiu a inserção dessa personagem desencadeadora de diferentes formas de pensar, contudo, simbolizando o novo, a narrativa vai ratificar a insuficiência dela para quebrar a tradição e resultando no discurso ambíguo quando nos deparamos com uma voz narrativa distinguindo a chamada 'velha ordem' e a 'época de liberdades, de modernismos', contrastando com a voz da personagem central que delimita a tênue fronteira ditada entre o ser e o parecer ser.

Estabelecidas a ordem e a desordem familiar a partir da conduta religiosa, pelo condutor da narrativa, Maria Luísa já não era a mesma dona de casa de antes. Não mais tinha a mania de ordem, o que, para muitas mulheres garantia uma vida moral bem equilibrada. A partir disso, a influência de Flávio é aqui elemento desencadeador do estado de desagregação e de apostasia a que foi submetida a 'rainha do lar'. Detectando a falência de sua educação, a protagonista esclarece a superficialidade de sua religião, embora reconheça a necessidade dela para uma melhor integração social, veste as máscaras sociais e se despe de suas crenças. Volta a frequentar a Liga das Senhoras, da qual fazia parte, embora lhe custasse muito fazer as coisas que fazia outrora, mas precisa fingir para viver, também porque não queria perder a consideração que os outros a atribuía. Em destaque, o prestígio e a distinção hierárquica conquistados no exercício da religiosidade exibidos por Maria Luísa confirmam o quanto estava apegada a uma sociedade que agora desprezava. O medo da mudança e, talvez, o ímpeto de incapacidade, ou mesmo o gosto por ser cotejada como senhora 'correta' a fez vestir de novo a 'sua velha personalidade' e 'sentiu bem dentro dela'.

Uma observação atenta a essa trama permite ver a crítica à manutenção da vida de aparência da protagonista que ocorre, de certa forma, pelo receio de perder alguns privilégios sociais, conquistados em sua vida burguesa. Com esse comportamento, Maria Luísa falava e fazia coisas que não acreditava mais, como se cresse. Segundo ela, "como se não soubesse que só há uma verdade: o mal, o mal contra o qual não vale lutar porque é invencível e inevitável" (PEREIRA, 2006, p. 99). Viu-se conduzida a seguir a lei comum, a normalidade, as posturas embasadas no fingimento, mesmo falseadas, constituem formas de controle social, necessárias para manter a ordem.

A narrativa vai nos mostrando distintas formas de se ver, seja através da religião, das relações fingidas criadas entre seus seguidores, seja através do encontro com Flávio, a protagonista percebe a diluição daquele universo exato, severo, hostil e maniqueísta da qual acreditava fazer parte. Nesse embate pessoal contra o bem e o mal, Maria Luísa destaca que a vida de aparência distancia aquelas senhoras das criaturas fracas que procuravam ajudar. 
Ou seriam, também elas, fantoches movidos por esse monstro ridículo e poderoso: a convenção, filha da hipocrisia... E por que não seriam?... Ela, que não fazia senão repetir as lições do monstro, não o fazia com menor aparência de boa fé. Sabia que nada significava o que dizia. E o dizia calorosamente. Como era boa e fácil a mentira (PEREIRA, 2006, p. 99).

Nota-se, na expressão supracitada, a revelação da descrença em que se converteram as práticas religiosas da protagonista. Atribui às convenções o termo 'monstro', como se indicando que tal sistema de educação manipula, falseia e impede o conhecimento de si próprio, tornando as pessoas boas ou más. Sendo assim, era mais fácil mentir e viver de aparência. Dessa forma, as senhoras, analisadas aqui como fantoches, manipuladas pelo sistema educacional, religioso e moral e pelos juízos preconcebidos, concretizando as práticas religiosas, são tão frágeis quanto aquelas pessoas a quem elas se sentem superiores e querem ajudar. Cegas no seu convívio, elas também precisam ser ajudadas para se verem através de outros modos.

E nesse intento é que a presença de uma menina cega torna-se um novo momento epifânico, revelador da crise existencial da personagem, assim como o fora o envolvimento com Flávio. Maria Luísa tomara para si a tarefa de preparar as roupas das primeiras comungantes, pois acreditava ser um 'bom meio de se desempenhar práticas de caridade', já que os 'pobres poderia dar aos ricos, ocasião de exercerem os preceitos caridosos da religião'. Entre as comungantes, uma menina cega chama a atenção de Maria Luísa. A menina cega achava que, no dia da primeira comunhão, um milagre a faria enxergar. Esse trecho é bastante revelador, uma vez que, a menina não passa a ver após a comunhão, mas explica à mãe que não foi dessa vez, mas será de outra. Com a negação do milagre, renasce a esperança da cega de que, embasada em sua fé, ela seguiria firme no propósito de ver, de alguma maneira, mediada pela religião. A protagonista pode ser comparada à cega ao passo que, segundo o desenrolar do enredo, também possuía uma forma de cegueira. Pois, passou toda a sua trajetória de vida sem entender a si mesma e aos outros, sem ver a verdade das relações e das crenças a que estava submetida, enclausurada numa posição de superioridade, impedida de ver seus erros, seus preconceitos e a parcialidade de suas convenções, o que configura uma forma de cegueira.

Traçando um paralelo entre as expectativas expostas no episódio em questão e as intencionalidades da protagonista, encontramos, na cega, a esperança de ver aquilo que todas as pessoas viam e acreditavam ser verdade. Do outro lado, Maria Luísa, após deixar de ver aquele universo aparente que a cega deseja ver, é que conseguiu de fato enxergar as verdades da sociedade em que vivia. Embora possuísse a visão perfeita era incapaz de enxergar, pois a sua condição modesta, a rigidez das convicções, sua educação religiosa a cegou de conhecer a realidade das tendências e das práticas familiares. Assim, para a protagonista, era necessário olhar além desses limites da aparência, alcançar o íntimo de cada ser a fim de buscar o seu conhecimento, evitando juízos preconcebidos. Nessa condição, mesmo quem não possuía problemas visuais não conseguia enxergar, a cegueira da protagonista era condicionada à dissimulação que nutria a sociedade e que, ainda ciente de sua existência, era necessário sustentá-la a fim de manter o controle familiar. Sendo 
assim, Maria Luísa enxergou, mas preferiu o fingimento, a negociação, a fim de manterse naquela sociedade machista. Assim como toda a narrativa vai sendo construída através das inquietações psicológicas do universo feminino, a protagonista enxerga a sua condição, mas negocia com a própria sociedade para manter-se numa condição privilegiada. Por conseguinte, como vimos reiterando, o papel da mulher contemporâneo à escritura da narrativa se limita, em grande medida, aos afazeres da casa e da educação dos filhos. Sob esse matiz, Maria Luísa simboliza bem a dona de casa exemplar e, mesmo vivendo outras experiências, retorna do prazer ao dever. Também ela, mesmo tendo contato com novas realidades, não foi dessa vez que mudou suas práticas, mas se se pensar na trajetória feminina na história, poder-se-ia pensar que seria de outra vez.

\section{REFERÊNCIAS}

BADINTER, Elisabeth. XY: sobre a identidade masculina. Rio de Janeiro: Rocco, 1993.

BUENO, Luís. Uma história do romance de 30. São Paulo: Editora da Universidade de São Paulo; Campinas: Editora da Unicamp, 2006.

CANDIDO, Antonio. Lúcia. In: O albatroz e o chinês. Rio de Janeiro: Ouro sobre azul, 2004. p. 127-132.

DEL PRIORE, Mary. História do amor no Brasil. São Paulo: Contexto, 2005.

MENDONÇA, Bernardo de. A leitora e seus personagens: profecias e memórias dos anos 30. In: PEREIRA, Lúcia Miguel. A leitora e seus personagens: seleta de textos publicados em periódicos (1931- 1943), e em livros. Prefácio, Bernardo de Mendonça; pesquisa bibliográfica, seleção e notas, Luciana Viégas- Rio de Janeiro: Grafia Editorial, 1992. p. xii-xx.

NOLASCO, Sócrates. De Tarz̧an a Homer Simpson: banalização e violência masculina em sociedades contemporâneas ocidentais. Rio de Janeiro: Rocco, 2001.

PEREIRA, Lúcia Miguel. Maria Luísa. In: PEREIRA, Lúcia Miguel. Ficção reunida. Curitiba: Ed. da UFPR, 2006.

WANDERLEY, Márcia Cavendish. Lúcia Miguel Pereira: do conservadorismo ao liberalismo. In: RAMALHO, Christina (Org.) Literatura e feminismo. Propostas teóricas e reflexões críticas. Rio de Janeiro: Elo Editora, 1999. p.73-84.

Recebido em: 06/03/217

Aprovado em: 23/05/2017

Publicado em: 01/06/2017 